MANNHEIM RESEARCh INSTITUTE FoR THE ECONOMics OF AGing

\title{
DOES SCHOOLING AFFECT HEALTH BEHAVIOR? EVIDENCE FROM EDUCATIONAL \\ EXPANSION IN WESTERN GERMANY
}

Hendrik Jürges, Steffen Reinhold and Martin Salm

๑) $\boldsymbol{m e a - M a n n h e i m ~ R e s e a r c h ~ I n s t i t u t e ~ f o r ~ t h e ~ E c o n o m i c s ~ o f ~ A g i n g ~}$

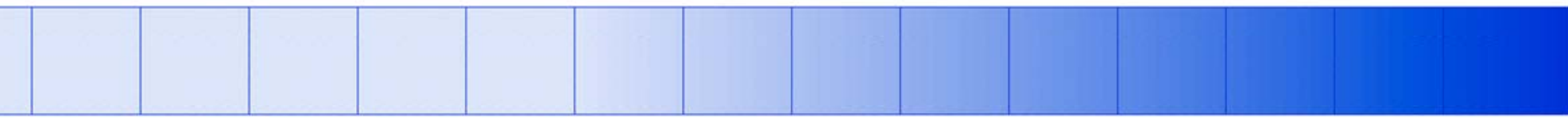

L13, 17_D-68131 Mannheim_Phone +49 621 181-2773/1862_Fax +49 621 181-1863_www.mea.uni-mannheim.de 


\title{
Does Schooling Affect Health Behavior? \\ Evidence from Educational Expansion in Western Germany*
}

\author{
Hendrik Jürges* $^{*} \quad$ Steffen Reinhold ${ }^{+} \quad$ Martin Salm ${ }^{\star}$
}

July 2009

\begin{abstract}
During the postwar period German states pursued policies to increase the share of young Germans obtaining a university entrance diploma (Abitur) by building more academic track schools, but the timing of educational expansion differed between states. This creates exogenous variation in the availability of higher education, which allows estimating the causal effect of education on health behaviors. Using the number of academic track schools in a state as an instrumental variable for years of schooling, we investigate the causal effect of schooling on health behavior such as smoking and related outcomes such as obesity. We find large negative effects of education on smoking. These effects can mostly be attributed to reductions in starting rates rather than increases in quitting rates. We find no causal effect of education on reduced overweight and obesity.
\end{abstract}

Keywords: Education, Smoking, Obesity

JEL-Codes: I12, I20

\footnotetext{
* We would like to thank seminar participants at MEA and at the Annual Meeting of the German Economic Association for valuable suggestions. We also would like to thank Daniel Kemptner, Finn Marten Körner and Jean-Marie Meier for their excellent research assistance in collecting the data on educational expansion in Germany.

* juerges@mea.uni-mannheim.de, MEA, University of Mannheim,

+ reinhold@mea.uni-mannheim.de, MEA, University of Mannheim

• M.Salm@uvt.nl, Tilburg University
} 


\section{Introduction}

There is a well documented positive relationship between higher levels of education and better health (see survey by Grossman 2006). This relationship can be found in many countries, and it holds at different education levels and for various indicators of health. One explanation why higher education might improve health is via health behaviors such as smoking or eating (Cutler and Lleras-Muney 2007). Higher education is associated with substantially lower rates of smoking and obesity, two important causes of premature deaths (Mokdad et al. 2004). For example, smoking rates in Germany are 48\% among low educated men, as opposed to $20 \%$ among men with college degrees (Deutsches Krebsforschungszentrum 2004). Education could improve health behaviors in a number of ways. Better educated people might be better informed about negative health consequences of smoking and overeating, either because they learned about these consequences in school, or because better educated people find it easier to obtain and evaluate such information (Kenkel 1991, Nayga 2000, de Walque 2007). Education could also influence health behavior through higher income, different social environments, a different sense of control, or an impact of education on time preferences (Fuchs 1982). However, the association between education and health behavior does not necessarily reflect a causal effect of education on behaviors. An alternative explanation for this association could be third factors that influence both education and health behavior such as for example cognitive ability or time preferences.

In this study we use increased access to academic-track schools in (West-) Germany as a natural experiment in order to estimate the causal effect of education on smoking and obesity. The German secondary school system is traditionally structured as a tracked system. ${ }^{1}$ After primary school (usually at age ten), children are sent to one of three main secondary school tracks. The Gymnasium, which we will refer to as "grammar school" in this paper, is the 
academically most demanding track, and it is the only track that provides direct entry into tertiary education. During the second half of the $20^{\text {th }}$ century, and especially during the late 1960s and the early 1970s the number of grammar schools increased rapidly which allowed more students to visit the academic track. In our study, we exploit differences in the time path of grammar school construction between German states as a source of institutional variation in education levels.

This study contributes to the emerging literature on the causal effect of education on nonmarket outcomes such as health, health behaviors and the effects of parents' education on child outcomes (see survey by Grossmann 2006). Recent studies on the effect of education on non-market outcomes mostly rely on variations in educational policies and other natural experiments as a source of exogenous variation in education attainment. Examples for such natural experiments include changes in minimum schooling requirements in the United States (Lleras-Muney 2005), the United Kingdom (Oreopolous 2006, Clark and Royer 2008, Lindeboom et al. 2008, Silles 2009), France (Albouy and Lequin 2008), and Denmark (Ahrendt 2005). Alternative sources of exogenous variations which have been exploited in recent studies include exemptions from military service (Grimard and Parent 2006, de Walque 2007, Cipollone et al. 2007), quarter of birth (Adams 2002), state unemployment rates (Arkes 2004), and differences between twins (Lundberg 2008). The opening of additional schools or colleges provides a further source of institutional variation which has been used to estimate non-market returns of education for the United States (Currie and Moretti 2003), Taiwan (Chou et al. 2007), and South Korea (Park and Kang 2008). The identification strategy in our study is based on the opening of additional grammar schools in Germany.

Studies which examine the causal effect of education on health behaviors such as smoking and related outcomes such as obesity provide mixed evidence. De Walque (2007), and Grimard and Parent (2007) find that increased college enrollment in order to avoid the draft

\footnotetext{
${ }^{1}$ A detailed description of the German school system can be found in Jonen and Eckardt (2004)
} 
during the Vietnam War decreased smoking rates. Kenkel et al. (2006) use variation in education policies such as variations in per capita educational spending as instrument and find some evidence for reductions in smoking rates among high school graduates, but not for reduced obesity. Park and Kang (2008) find no statistically significant effect of education on smoking and obesity for men in South Korea, and Lundborg (2008) finds no significant effect of education on smoking and obesity based on a sample of American twins.

Our study adds to the existing literature by studying the causal link between education to health behaviors for a different institutional environment which has not been examined before. This allows gaining additional insights about the nature of this relationship and underlying pathways. Increased access to grammar schools in Germany has an impact on several dimensions of educational opportunities: 1) In Germany, grammar schools typically require nine years of secondary education, while the two other tracks of secondary education typically involve at most six years of secondary schooling (Jonen and Eckardt 2004). Thus, increasing enrollment in German grammar schools implies that more students will spend additional years in secondary education. 2) Upon finishing grammar school successfully, young adults in Germany are awarded a general university-entrance diploma called Abitur. The Abitur is thus both a high school graduation certificate and a university entrance exam. Since the university entrance exam is usually only awarded at grammar schools, the chosen track has major effects on the entire life course mainly through labor market outcomes (see e.g. Dustmann 2004). 3) Increased access to grammar schools has an impact not only on years of schooling, but also on the quality of education. Grammar schools have an academically more demanding curriculum than other tracks of secondary education. Moreover, teachers at grammar schools receive higher pay, have lower teaching requirements, and must fulfill stricter educational requirements (Kultusministerkonferenz 2008). Evidence from Northern Ireland suggests that increasing enrollment in grammar schools can boost academic achievement (Maurin and McNally 2007). 4) Most previous studies focus on changes in 
access to education that affect students at an age when many of them have already started smoking. Enrollment in German grammar schools typically starts at age ten, well before students usually start smoking.

Smoking rates for teenagers in Germany differ between tracks of secondary schooling, and they are lowest for students who attend grammar schools (Deutsches Krebsforschungszentrum 2004).

Using data from the German Microcensus (an annual survey of $1 \%$ of the German adult population) for the years 1999 and 2003, we find a large causal effect of higher education on decreased smoking, which can be mainly attributed to reduction of the onset of smoking. In contrast, we find no effect of higher education on reduced overweight and obesity. Our findings suggest that the results which previous studies such as Kenkel et al. (2006) and Grimard and Parent (2007) have established for the United States also apply to other developed countries such as Germany.

\section{Institutional Background}

In the second half of the $20^{\text {th }}$ century, and especially during the 1960 s and 1970 s, German education policy aimed at increasing the share of students obtaining a university-entrance diploma. In the course of this expansion, the number of grammar schools in Germany was increased from 1,583 in the year 1950 to 2,441 in the year 1990 (Statistisches Bundesamt, Series 11). One reason for this increased investment in education was a widespread concern that without an increase in the number of skilled graduates the West German economy would not be able to compete with communist rivals (Picht 1964). Another concern was to increase access to higher education for previously underrepresented groups such as girls, children of less educated parents, and children in rural areas. In an influential book, Dahrendorf (1965) 
argued that a highly educated population was a prerequisite for a stable and vibrant democracy.

--- about here Figure 1 ---

The extent of the educational expansion in Germany is illustrated in Figure 1, which shows the proportion of men and women in successive birth cohorts who obtained a universityentrance diploma. Figure 1 also shows trends in years of schooling. This measure includes years spent in primary and secondary education (as described in the following section). Whereas in the 1950s only around 5\% of a birth cohort graduated with a university-entrance diploma this number has increased to around a third by today. Shortly after World War II graduation rates were much higher for men than for women. In the meantime, this gap has disappeared, and today women are slightly more likely to graduate with a university-entrance diploma than men. Figure 1 also shows that average years in school rose alongside with the proportion of graduates with a university-entrance diploma.

In Germany, the states are responsible for education policy. State governments decide independently about the opening of new schools, the capacity of schools, the hiring of teachers, and the allocation of teachers to schools. Our identification strategy is based on the fact that the educational expansion path differed across federal states Some state governments increased the number and size of grammar schools faster than other states, creating (exogenous) variation in the accessibility of higher education.

--- about here Figure 2 ---

In Figure 2 we present numbers of schools per sq km for the eight Western German states (we exclude the city-states of Hamburg, Bremen, and West-Berlin). While there was a marked activity in building new academic track schools during the 1960s and 1970s in all states, there are important differences in the timing. Some states like North-Rhine Westphalia were leaders, other states like Hesse lagged behind in building schools. These differences in timing 
are important because enrolment in academic track schools followed very closely the constructions of new schools as the example of North-Rhine Westphalia in Figure 3 shows.

--- about here Figure 3---

These differences in global time paths of educational expansion reflect factors such as electoral cycles and political preferences of state governments (Hadjar and Becker 2006). The number of teachers was often increased just before and just after state elections. State governments also differed in their preferences for increasing grammar school attendance. While some governments focused on improving access of higher education, and especially on providing more educational opportunities for children in rural areas, and for children of less educated parents, other state governments were more concerned about keeping up standards and not diluting the quality of grammar schools by accepting too many marginal students. Our identifying assumption - explained in more detail in the next section - is that variations in the number of schools are exogenous determinants of individual education decisions.

\section{Identification strategy}

As a first step we use a linear probability model to assess the association between education and health behaviors. Consider the following OLS regression equation:

$$
H_{c s i}=E_{c s i} \beta+X_{c s i}^{\prime} \gamma+\bar{h}_{c}+\bar{h}_{s}+h_{c s i} ; h_{c s i}=\bar{h}_{c s}+\eta_{c s i}
$$

where $H_{c s i}$ is health behavior of individual $i$ in state $s$ born in cohort $c, E_{c s i}$ is years of schooling, $X_{c s i}$ are covariates such as a fourth-order polynomial in age, and a dummy for German nationality. $\bar{h}_{c}$ and $\bar{h}_{s}$ are fixed effects for annual birth cohorts and state of residence. The composite error term $h_{c s i}$ consists of $\bar{h}_{c s}$, an idiosyncratic cohort-state shock, and $\eta_{c s i}$, an idiosyncratic individual shock. 
When we estimate the coefficient on educational attainment in equation (1) we cannot be sure to have identified the causal effect of education on health behaviors. A positive coefficient on years of education can have different interpretations. One is that education directly positively affects health behavior. For example, if education provides better information on health risks, better educated people may abstain from risky behavior. In this case, education would be causal for health outcomes. Another explanation is self-selection. For example, individuals discounting the future only lightly will choose higher levels of education and also invest more in their health capital. But education would not be directly causal for health outcomes.

For this reason we use linear IV estimation with our instrumental variable being the number of academic track schools standardizes by the state area at the time when respondents were 10 years old. This is the age at which students typically leave primary school and start attending one of the three different types of secondary schools.

Our regression model can be written as:

$$
\begin{aligned}
& H_{c s i}=E_{c s i} \beta+X_{c s i}{ }^{\prime} \gamma+\bar{h}_{c}+\bar{h}_{s}+h_{c s i} ; h_{c s i}=\bar{h}_{c s}+\eta_{c s i} \\
& E_{c s i}=Z_{c s}{ }^{\prime} \delta+X_{c s i}{ }^{\prime} \varphi+\bar{e}_{c}+\bar{e}_{s}+e_{c s i} ; e_{c s i}=\bar{e}_{c s}+\varepsilon_{c s i}
\end{aligned}
$$

where $\bar{h}_{c}, \bar{h}_{s}$ and $\bar{e}_{c}, \bar{e}_{s}$ are common shocks for cohort $c$ and a fixed effect for state $s$ for health behaviors and for education, respectively, $\bar{h}_{c s}$ and $\bar{e}_{c S}$ are idiosyncratic state-cohort specific shocks, $X_{c s i}$ are other exogenous variables such as German nationality, and a fourthorder polynomial in age, $\eta_{c s i}$ and $\varepsilon_{C S i}$ are individual-specific shocks, and finally $\beta$ is the coefficient on years of schooling, the parameter of interest. $Z_{c s}$ is the instrument, the number of academic track schools $/ \mathrm{km}^{2}$. We can decompose the value of the instrument for an individual in cohort $c$ and state $s$ into common cohort and state components and an idiosyncratic cohort-state component: 


$$
Z_{c s}=\bar{Z}_{c}+\bar{Z}_{s}+\bar{Z}_{c s}
$$

The proper treatment of trends is very important for our identification strategy. Both individual education levels and health related behaviors were subject to large secular changes since World War II, and similarly our instruments also exhibit a strong secular upwards trend. In our specification, we use fixed effects for annual birth cohorts and for states of residence in order to account for secular trends in all variables and also for permanent differences between states. After partialing out observable exogenous variables, cohort and state fixed effects we obtain:

$$
\begin{aligned}
& \widetilde{H}_{c s i}=\widetilde{E}_{c s i} \beta+\bar{h}_{c s}+\eta_{c s i} \\
& \widetilde{E}_{c s i}=\widetilde{Z}_{c s}{ }^{\prime} \delta+\bar{e}_{c s}+\varepsilon_{c s i} \\
& \widetilde{Z}_{c s}=\bar{Z}_{c s}
\end{aligned}
$$

We can now discuss the assumptions for the instrument in this transformed model. First, the instrument must still possess enough explanatory power. Second, the instruments must be valid. Since we do not model state-specific cohort trends in this specification, the idiosyncratic state-cohort shock $\bar{h}_{c s}$ is included in the composite error term. Validity of our instrument thus requires

$$
\operatorname{Corr}\left(\bar{z}_{c S}, \bar{h}_{c S}\right)=\operatorname{Corr}\left(\bar{z}_{c S}, \eta_{c s i}\right)=0
$$

This assumption requires that shocks to the expansion path on the state level must not be correlated either with the individual component of health behaviors or with shocks affecting smoking behavior or weight problems at the state level. We believe that this is reasonable since health policy is implemented on the federal level and not on the state level. ${ }^{2}$ Tobacco taxes are also set at the federal level.

\footnotetext{
${ }^{2}$ Only very recently, regulations on smoking-bans in restaurants and bars have been implemented on the state level.
} 
Summing up, we use for identification state-specific deviations in their educational expansion from a joint federal trend. There were states expanding their educational system earlier as for instance North-Rhine Westphalia while others like Hesse were laggards. This variation induces exogenous variation in access to higher secondary education. When we control for state-specific cohort trends we encounter the problem that we discard this variation. We tried specifications in which we also control for state-specific linear cohort effects, but in this case our instruments lose their explanatory power.

If we allow for heterogeneous treatment effects, the IV estimator does not identify the causal effect of schooling for the whole population, but instead identifies the local average treatment effect (LATE), that is the effect on individuals whose treatment status is changed by virtue of the instrument (Imbens and Angrist, 1994). Our results can thus be interpreted as the causal effect for (marginal) individuals who were brought into higher education because of positive shocks to the educational expansion in their age-state cohort. This effect may be different from the effect for the whole population but it is still very relevant. A further expansion of the educational system would induce a similar variation in access to higher education and one could hope to reap similar benefits of education as those we try to identify here.

\section{Data description}

We use data from the German Microcensus for the years 1999 and 2003. The Microcensus is an annual survey which is collected by the German Federal Statistics Office and covers a 1\% sample of the German population. The Microcensus is based on a rotating scheme such that individuals in the same household are re-interviewed up to four times. However, individuals or households cannot be identified across waves. The samples for 1999 and 2003 do not include repeated records for the same individual or household, and are thus independent random samples. Participation in the Microscensus is mandatory. However, answers to some 
questions such as for example questions about health behaviors are voluntary. Moreover, questions about health behaviors are asked of a $45 \%$ random subsample of participants only. In our estimation sample we exclude observations for (a) individuals with foreign nationality unless they were born in Germany, (b) individuals younger than 21 or older than 63 and (c) respondents not living in one of the former Western German states. The age restrictions are due to the possibility that respondents younger than 21 might still be in school if they have repeated grades (the usual age one obtains the university-entrance diploma is 19), and due to the fact we only have information on school constructions starting with the 1940 birth cohort. Descriptive statistics for the variables used in our analyses are shown in Table 1.

\section{--- about here Table 1 ---}

Outcome variables in our studies are starting and stopping smoking, being overweight and being obese. Based on self-reports, we construct three binary variables for smoking behavior, one for respondents who smoke currently, one for respondents who ever smoked, and one for respondents who quit smoking. This allows a detailed analysis of differences in smoking behavior across educational groups. In total, 38\% of men in our sample are current smokers, $59 \%$ have ever smoked, and $36 \%$ of the ever smoking group has quit smoking. The corresponding shares for women are $29 \%$ for current smokers, and $45 \%$ for ever smokers, of whom $36 \%$ are past smokers. Figure 4 shows trends in the proportion of respondents who ever smoked, who currently smoke and who stopped smoking, separately for men and women across birth cohorts. We find higher current smoking rates for men than to women. This difference has decreased considerably for younger birth cohorts. Current smoker rates tend to decrease in age. However, the proportion of respondents who ever smoked peaks for cohorts born around the late 1950s for both sexes, and is lower for younger cohorts. Older persons are more likely to have quit smoking.

---about here Figure 4--- 
Variables for overweight and obesity are based on survey questions about respondents' height and weight. Based on this information we compute the body mass index (BMI) and categorical variables for overweight (BMI greater than 25), and obesity (BMI greater than 30). In total, $55 \%$ percent of men in our sample are overweight and $12 \%$ are obese. Among women, 33\% are overweight and 9\% are obese. Figure 5 shows how rates of overweight and obesity vary across birth cohorts. Rates of overweight and obesity strongly increase with age for both men and women.

---about here Figure 5---

The Microcensus does not ask explicitly about years of schooling. Instead, our measure for education is based on categorical information on the highest secondary school degree obtained. Together with information on the number of years it typically takes to obtain this degree this allows us to compute a variable for years in school. This variable includes years of schooling in primary and secondary education, but does not include years spent in tertiary education or in vocational training. Our method to measure years of schooling in Germany follows previous studies such as Pischke and von Wachter (2008). Answers to questions about education in the Microcensus are mandatory only for respondents up to age 51. For older respondents the answers are voluntary. The average number of years in school is 10.15 years for men and 10.02 years for women. An additional explanatory variable is a binary indicator for German nationality. Individuals without German nationality were only included in the study if they are born in Germany because these individuals went through the German educational system. This explains the rather low number of individuals without German nationality. The instrumental variable for years in school, the number of grammar schools per square kilometer in the state of residence at the time when the respondent was 10 years old, are based on information obtained from the federal statistics office (Ferderal Statistics Office, Series 11). 


\section{Estimation Results}

Table 2 shows our OLS estimation results. The table shows the association between smoking and weight problems and years of schooling after controlling for German nationality, fixed effects for states of residence and annual birth cohorts as well as a fourth order polynomial in age.

--- about here Table 2 ---

We find a strong association between education and better health behaviors. The better educated smoke less both because they are more likely to never have started, and conditional on having started they quit smoking more often. One year of additional schooling is associated with a reduction in current smoking rates of 3.7 percentage points for women and 4.5 percentage points for men. Furthermore, the better educated are also less likely to be overweight or obese. One additional year of schooling reduces the risk of being overweight by 4.4 percentage points for women and by 3.6 percentage points for men, and obesity rates are reduced by 1.9 percentage points for women and by 1.8 percentage points for men. The gender differences in the association between education and health behaviors are not large. These results confirm the findings of previous studies which also find a strong association between higher education and better health behaviors, both in Germany (Deutsches Krebsforschungszentrum 2004) and in other countries (Cutler and Lleras Muney 2008). If these OLS estimates were interpreted causally they would suggest very large effects of education on health related behavior.

Table 3 shows our instrumental variables estimation results using as instrument the number of grammar schools per sq $\mathrm{km}$ in the state of residence when the respondent was age 10 . As before, we control for German nationality, a fourth-order polynomial in age, and fixed effects 
for state of residence and annual birth cohorts. For women, we find that one additional year in academic track reduces current smoking rates by about 6 percentage points. This effect is larger than the corresponding OLS estimate, and it suggests a large beneficial effect of higher educational attainment.

---about here Table 3---

Higher education reduces current smoking rates mainly because education prevents individuals to start smoking in the first place. One additional year of schooling reduces the probability of ever smoking for women by around 12 percentage points. The effect on quitting is smaller and not statistically significant. The results for men mirror the effects for women. Education has a strong negative effect on current smoking rates mainly through its effects on the probability of starting smoking. However, estimation coefficients are even larger for men than for women. One additional year of schooling reduces smoking rates by about 15 percentage points, and reduces the probability of ever having smoked by around 19 percentage points. These effects seem very large. However, they do not represent average treatment effects for the population, but local average treatment effects for students at the margin of attending Grammar School. It is possible that the effect of education on smoking is especially large for this group.

How do our results compare to the previous literature? Previous studies also tend to find that higher education reduces smoking. While these negative effects are not statistically significant in Park and Kang (2008) and Lundborg (2008), studies by Kenkel et al. (2006) and Grimard and Parent (2007) also find large and significant effects of higher education on less smoking. For these two studies, IV estimates for the effects of higher education on reduced smoking are larger than OLS estimates, and the estimated IV effects are even larger than in our study. As in our study, Kenkel et al. find that the effect of education on smoking is larger for men than for women. The results in our study also confirm the results by both Kenkel et al. and 
Grimard and Parent that the effect of education on reduced smoking can be attributed mainly to reduced onset of smoking as opposed to an increase in quitting behavior. Thus, our findings on the effect of higher education on smoking behavior show that results for the United States obtained in previous studies also apply to Germany.

Our results further indicate that education increases the probability of overweight and obesity. This effect is not statistically significant for women, but it is large and statistically significant for men. While this result might seem surprising, attending grammar school might be related to changes in lifestyle that can increase the risk of overweight and obesity such as a switch from manual blue collar work to more sedentary white collar employment. At the very least, our estimation results allow us to reject the notion that higher education reduces overweight and obesity.

As for smoking, our results for overweight and obesity also confirm results from previous studies. Kenkel et al. also find a positive effect of years of education on overweight for both men and women. Their estimate is of a similar size as in our study, but it is not statistically significant. In his sample of twins, Lundborg (2008) also finds that higher education causes an (insignificant) increase in BMI.

First stage F-statistics for our instrumental variable range from 12 to around 30, which indicates that our instrument is not weak (Staiger and Stock 1997). However, F-statistics are lower for men than for women. This can be explained because the educational expansion affected women more than men. Thus, we put more credibility in our estimation results for women. 


\section{Robustness of the Results}

\subsection{Restriction of the Sample to Older Birth Cohorts}

In our specification, we use birth cohorts born between 1940 and 1980, and we hope to capture all relevant trends through the use of birth cohort dummies, state fixed-effects, and a fourth-order polynomial in age. We might be worried that the time period is too long, such that uncontrolled trends at the state-level bias our results. In addition, our instruments do not have much variation for birth cohorts born after the late 1960s because for these cohorts the educational expansion stagnated in Germany. For this reason, in an alternative specification we restrict our sample to the birth cohorts born between 1940 and 1965, and present the results in Table 4.

---about here Table 4---

For women, there are no large differences in the estimates for the complete sample versus the restricted sample. The instrument becomes somewhat weaker, but it does not become too weak. The qualitative conclusion remains, education reduces smoking rates mainly by preventing individuals from starting smoking. For men, however, a different picture emerges. While the point estimators for the effects of education are similar to the estimates in the complete sample, the instruments become very weak making inference very difficult. The weakness of the instruments points to the fact that women profited more from the educational expansion than men. Immediately after World War II, men had higher educational attainment than women, but this relationship has reversed since then. For the relevant cohorts our instrument does only have weak explanatory power for educational attainment of men. For this reason, we put more confidence in our results for women. 


\subsection{Internal Migration}

One potential problem of our identification strategy is that we use information on the current location of the individuals, but we do not know the exact location of individuals at age 10 . This problem is not unique to our study (see, for example, Pischke and von Wachter 2008). In auxiliary analyses using the German SOEP we estimated the migration probabilities of individuals across states and found that mobility is fairly low with only $17 \%$ of all individuals leaving the state where they finished school. However, we have found somewhat higher mobility in and out of the city-states Berlin, Hamburg, and Bremen (33\%). Although the population in these states accounts for less than 5 percent of the German population, we have excluded these states from our analysis.

\section{Conclusion}

In this paper, we examine the question whether and to what extent the strong association between better education and better health and health behaviors reflects a causal effect of education on health behaviors. We use cross-state variation in the educational expansion in Western Germany as instruments to account for the endogeneity of the individual's education. During the postwar period German states pursued policies to increase the share of young Germans obtaining a university entrance diploma (Abitur) by building more academic track schools, but the timing of the educational expansion differed between states. This creates exogenous variation in the availability of higher education, which allows estimating the causal effect of education on health behaviors.

Economists have long recognized the importance of education as a determinant of an individual's wages. The positive effect of education on health and health behaviors could be another important return to education. We find that education has a strong protective effect against smoking. This effect can mainly be attributed to the effect of education on reduced 
onset of smoking, as opposed to the effect of education on increased quitting behavior. Our findings suggest that the results which previous studies such as Kenkel et al. (2006) and Grimard and Parent (2007) have established for the United States also apply to other developed countries such as Germany. We interpret our causal estimate as the local average treatment effect for individuals at the margin of attending academic track. Such people are especially sensitive to changes in educational opportunities, and hence policy can affect their educational decision. Our findings suggest that the effect of education on smoking might be very large for this group. In contrast, we do not find that education generally reduces weight problems. It remains an open question what aspects of education lead to an improvement in one domain of health behavior while potentially even leading to worse health behavior in other domains. One explanation is that the dangers of smoking became widely known during the educational expansion while awareness of the dangers of overweight is discussed only in recent years. If education helps in processing new information on health related behaviors this could explain why we find an effect on smoking but not on overweight.

\section{References}

Adams, S.J. (2002), Educational attainment and health: evidence from a sample of older adults. Education Economics, 10, 97-109.

Ahrendt, Jakob (2005), Does education cause better health? A panel data analysis using school reform for identification. Economics of Education Review. 24, 149-160.

Albouy, V., and L. Lequien (2009). Does compulsory education lower mortality? Journal of Health Economics, $28,1,155-168$.

Arkes (2001), Does schooling improve adult health? Working Paper, RAND Corporation

Card, David (1999), The Causal Effect of Education on Earnings. in O. Ashenfelter and D. Card (eds.) Handbook of Labor Economics, Vol. 3. Elsevier Science B.V.

Chou, Shin-Yi, Jin-Ta Liu, Michael Grossmann, Ted Joyce (2007). Parental education and child health: evidence from a natural experiment in Taiwan. Working Paper.

Cipollone, Piero, Debora Radicchia, and Alfonso Rosolia (2007). The effect of education on youth mortality. Working Paper.

Clark, Damon, and Heather Royer (2008). The effect of education on adult mortality: Evidence from the United Kingdom. Working Paper.

Currie, Janet and Enrico Moretti (2003), Mother's education and the intergenerational transmission of human capital: evidence from college openings. Quarterly Journal of Economics, 118(4), 1495-1532.

Cutler, David, and Adriana Lleras-Muney (2007). Understanding differences in health behaviors by education. Working Paper. 
Cutler, David, and Adriana Lleras-Muney (2008). Education and Health: Evaluating theories and evidence. In: The effects of social and economic policy on health. Editors: J. Newhouse, R. Schoeni, G. Kaplan, and H. Polack, forthcoming, Russell Sage Press.

Dahrendorf, Ralf (1965). Bildung ist Buergerrecht: Plaedoyer fuer eine aktive Bildungspolitik. Nannen Verlag.

De Walque, Damien (2007), Does education affect smoking behaviors? Evidence using the Vietnam draft as an instrument for college education, Journal of Health Economics, 26, 877-895.

Deutsches Krebsforschungszentrum (2004). Rauchen und soziale Ungleichheit - Konsequenzen für die Tabakkontrollpolitik [Smoking and Health Inequality - Implications for tobacco control policy]. Heidelberg.

Dustmann, Christian (2004). Parental Background, Secondary School Track Choice, and Wages. Oxford Economic Papers 56, 209-230.

Fuchs, Victor (1982). Time Preference and Health: An Explanatory Study. pp. 93-120 in: VR Fuchs - Economic aspects of health, University of Chicago Press.

Grimard, F. and D. Parent (2007), Education and Smoking: Were Vietnam draft avoiders also more likely to avoid smoking? Journal of Health Economics, 26, 896-926.

Grossman, Michael (2006). Education and non-market outcomes. In: Handbook of the Economics of Education, edited by: Eric Hanushek and Finis Welch, Elsevier Science.

Hadjar, A. and R. Becker (2006): Die Bildungsexpansion: erwartete und unerwartete Folgen. [The Educational Expansion: Expected and Unexpected Consequences]. Wiesbaden: VS Verlag.

Imbens, Guido W. and Joshua D. Angrist (1994). Identification and estimation of local average treatment effects. Econometrica, 62, 467-475.

Jonen, Gerdi \& Thomas Eckardt (2006). "The Education System in the Federal Republic of Germany 2004." Secretariat of the Standing Conference of the Ministers of Education (KMK). http://www.kmk.org/ dossier/dossier_en_ebook.pdf [2007, Jan 12].

Kenkel, Donald (1991). Health behavior, health knowledge, and schooling. Journal of Political Economy, 99, 287-305.

Kenkel, Donald, Dean Lillard, and Alan Mathios (2006). The roles of high school completion and GED receipt in smoking and obesity. Journal of Labor Economics, 24(3), 635-659.

Klein, Thomas, Rainer Unger, and Alexander Schulze (2006). Bildungsexpansion und Lebenserwartung in Andreas Hadjar and Rolf Becker (eds.), Die Bildungsexpansion. Erwartete und unerwartete Folgen. VS Verlag für Sozialwissenschaften, Wiesbaden.

Kultusministerkonferenz (2008). Bildung in Deutschland 2008. Bertelsmann Verlag, Bielefeld.

Lindeboom, Maarten, A. Llena-Nozal, Bas van der Klauuw (2009). Parental education and child health: evidence from a schooling reform. Journal of Health Economics, 28, 109-131.

Lleras-Muney, Adriana (2005), The relationship between education and adult mortality in the U.S. Review of Economic Studies, 72, 189-221.

Lundborg, Petter (2008). The health returns to education- what can we learn from twins? IZA DP3399.

Maurin, Erin, and Sandra McNally (2007). Educational effects of widening access to the academic track: a natural experiment. Working Paper.

Mokdad, Ali H,, James S. Marks, Donna F. Stroup, and Julie F. Gerberding (2004). Actual causes of death in the United States, 2000. Journal of the American Medical Association, 291, 1238-1245.

Nayga, Rudolfo M. (2000). Schooling, health knowledge, and obesity. Applied Economics, 32, 815-832.

Oreopolous, Philip (2006), Estimating average and local average treatment effects of education when compulsory school laws really matter. American Economic Review, 96, 152-175.

Park, Cheolsung, and Changhui Kang (2008). Does education induce healthy lifestyle? Journal of Helath Economics, 27, 1516-1531.

Picht, Georg (1964). Die deutsche Bildungskatastrophe: Analyse und Dokumentation. Walter Verlag. Olten.

Silles, Mary (2009). The causal effect of education on health: Evidence from the United Kingdom. Economics of Education Review 28: 122-128. 
Staiger, Douglas and James H. Stock, 1997. Instrumental Variables Regression with Weak Instruments, Econometrica 65, 557-586.

Statistisches Bundesamt. Fachserie 10+11, various issues. 


\section{Tables and Figures}

Table 1. Summary Statistics: Mean, Standard deviation, and number of observations.

\begin{tabular}{lcc} 
& Women & Men \\
\hline Health Variables & & \\
Currently Smoking & 0.29 & 0.38 \\
& $(0.45)$ & $(0.48)$ \\
Ever Smoked & {$[74759]$} & {$[74542]$} \\
& 0.45 & 0.59 \\
Quitted Smoking & $(0.50)$ & $(0.49)$ \\
& {$[74112]$} & {$[74013]$} \\
Overweight & 0.36 & 0.36 \\
& $(0.48)$ & $(0.48)$ \\
Obese & {$[33604]$} & {$[43812]$} \\
& 0.33 & 0.55 \\
& $(0.47)$ & $(0.50)$ \\
Individual Characteristics & {$[62719]$} & {$[64336]$} \\
Years of Education & 0.09 & 0.12 \\
& $(0.29)$ & $(0.32)$ \\
& {$[62719]$} & {$[64336]$} \\
Age & 10.02 & \\
& $(1.72)$ & 10.15 \\
& {$[80908]$} & $(1.82)$ \\
German Nationality & 41.87 & {$[81290]$} \\
& $(11.20)$ & 41.76 \\
& {$[87581]$} & $(11.13)$ \\
& 0.99 & {$[87602]$} \\
No. & $(0.10)$ & $(0.11)$ \\
& {$[87581]$} & {$[87602]$}
\end{tabular}

Notes: Standard deviations in parentheses and number of observations in square brackets. 
Table 2: OLS regression results for the effect of education on health behavior

\begin{tabular}{lccccc}
\hline & $\begin{array}{c}\text { Currently } \\
\text { Smoking }\end{array}$ & Ever Smoked & $\begin{array}{c}\text { Quitted } \\
\text { Smoking }\end{array}$ & Overweight & Obese \\
\hline Panel A: Women & & & & & \\
Years of education & $-0.037^{\star \star *}$ & $-0.028^{\star \star \star}$ & $0.041^{\star \star \star}$ & $-0.044^{\star \star *}$ & $-0.019^{\star \star \star}$ \\
& $(0.002)$ & $(0.002)$ & $(0.002)$ & $(0.001)$ & $(0.001)$ \\
Number of obs. & 71353 & 70755 & 32215 & 60139 & 60139 \\
& & & & & \\
Panel B: Men & & & & & \\
Years of education & $-0.045^{\star \star *}$ & $-0.041^{\star \star *}$ & $0.030^{\star \star *}$ & $-0.036^{\star \star *}$ & $-0.018^{\star \star \star}$ \\
& $(0.002)$ & $(0.002)$ & $(0.002)$ & $(0.001)$ & $(0.001)$ \\
Number of obs & 71388 & 70903 & 42030 & 61892 & 61892 \\
\hline
\end{tabular}

Note: A dummy for German nationality, a fourth-order polynomial in age, and state and cohort-specific fixed effects are included. Robust standard errors (clustered on state-cohort cells) in parentheses.

Significance at ${ }^{* *} 1 \% * * 5 \% * 10 \%$ level. 
Table 3: IV regression results for effect of education on health behaviors.

\begin{tabular}{lccccc}
\hline & $\begin{array}{c}\text { Currently } \\
\text { Smoking }\end{array}$ & Ever Smoked & $\begin{array}{c}\text { Quitted } \\
\text { Smoking }\end{array}$ & Overweight & Obese \\
\hline Panel A: Women & & & & & \\
Years of education & $-0.061^{*}$ & $-0.116^{\star \star \star}$ & 0.019 & 0.061 & 0.012 \\
& $(0.036)$ & $(0.042)$ & $(0.046)$ & $(0.038)$ & $(0.024)$ \\
First-stage F statistic & 29.81 & 29.43 & 24.07 & 29.03 & 29.03 \\
Number of obs. & 71353 & 70755 & 32215 & 60139 & 60139 \\
& & & & & \\
Panel B: Men & & & & & \\
Years of education & $-0.150^{\star \star \star}$ & $-0.186^{\star \star \star}$ & 0.051 & $0.123^{*}$ & $0.133^{\star \star \star}$ \\
& $(0.056)$ & $(0.060)$ & $(0.057)$ & $(0.068)$ & $(0.051)$ \\
First-stage F statistic & 18.43 & 17.43 & 13.96 & 12.87 & 12.87 \\
Number of obs & 71388 & 70903 & 42030 & 61892 & 61892 \\
\hline
\end{tabular}

Note: A dummy for German nationality, a fourth-order polynomial in age, and state and cohort-specific fixed effects are included. Robust standard errors (clustered on state-cohort cells) in parentheses. Significance at ${ }^{\star \star \star} 1 \% * \star 5 \% * 10 \%$ level. 
Table 4: IV regression results for health behaviors, sample restricted to persons born before 1965

\begin{tabular}{|c|c|c|c|c|c|}
\hline & $\begin{array}{l}\text { Currently } \\
\text { Smoking }\end{array}$ & Ever Smoked & $\begin{array}{l}\text { Quitted } \\
\text { Smoking }\end{array}$ & Overweight & Obese \\
\hline \multicolumn{6}{|l|}{ Panel A: Women } \\
\hline Years of education & $\begin{array}{l}-0.063 \\
(0.057)\end{array}$ & $\begin{array}{c}-0.124^{* \star} \\
(0.062)\end{array}$ & $\begin{array}{c}0.023 \\
(0.065)\end{array}$ & $\begin{array}{c}0.088 \\
(0.063)\end{array}$ & $\begin{array}{c}0.018 \\
(0.038)\end{array}$ \\
\hline First-stage F statistic & 16.55 & 16.97 & 16.83 & 14.67 & 14.67 \\
\hline Number of obs. & 48280 & 47859 & 21928 & 40824 & 40824 \\
\hline \multicolumn{6}{|l|}{ Panel B: Men } \\
\hline Years of education & $\begin{array}{c}-0.087 \\
(0.102)\end{array}$ & $\begin{array}{l}-0.164 \\
(0.117)\end{array}$ & $\begin{array}{l}-0.009 \\
(0.099)\end{array}$ & $\begin{array}{c}0.143 \\
(0.166)\end{array}$ & $\begin{array}{c}0.228 \\
(0.165)\end{array}$ \\
\hline First-stage F statistic & 5.15 & 4.56 & 5.26 & 2.84 & 2.84 \\
\hline Number of obs & 48200 & 47886 & 29995 & 41934 & 41934 \\
\hline
\end{tabular}


Figure 1: Graduates of Academic Track Schools and Years of Education.

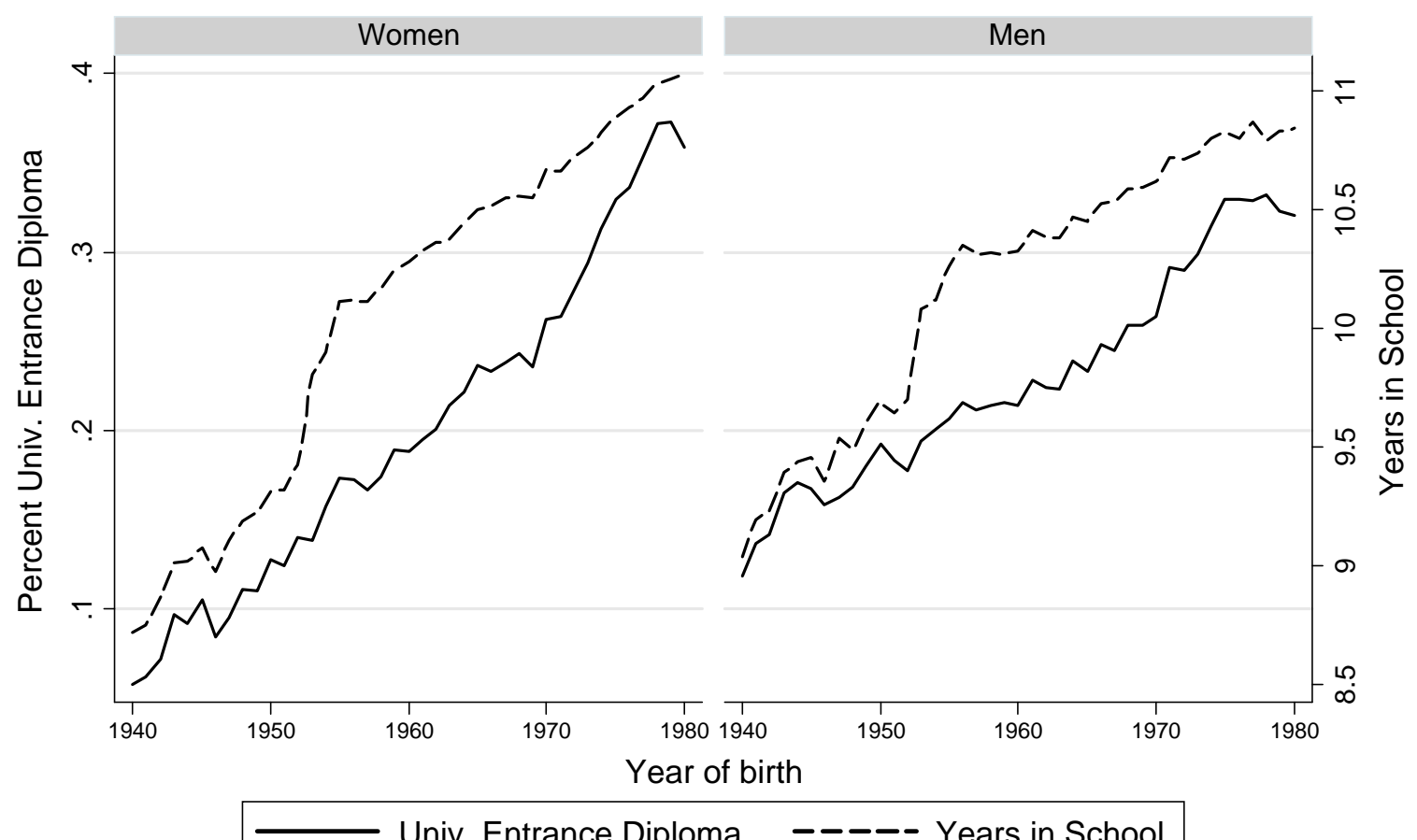


Figure 2: Schools per sq km

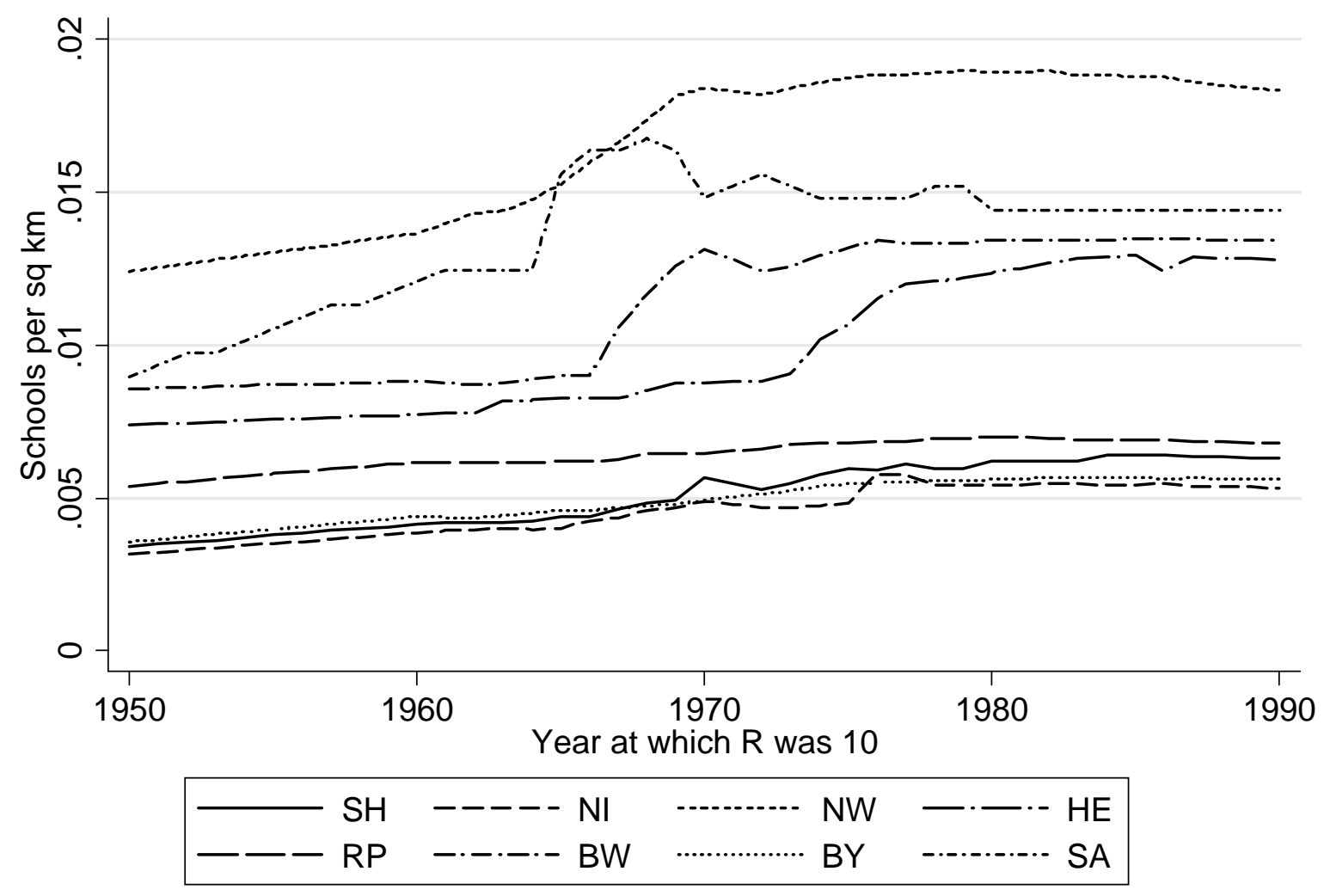


Figure 3: Schools per sq km and proportion of students graduating from academic track school for the state of North-Rhine Westphalia

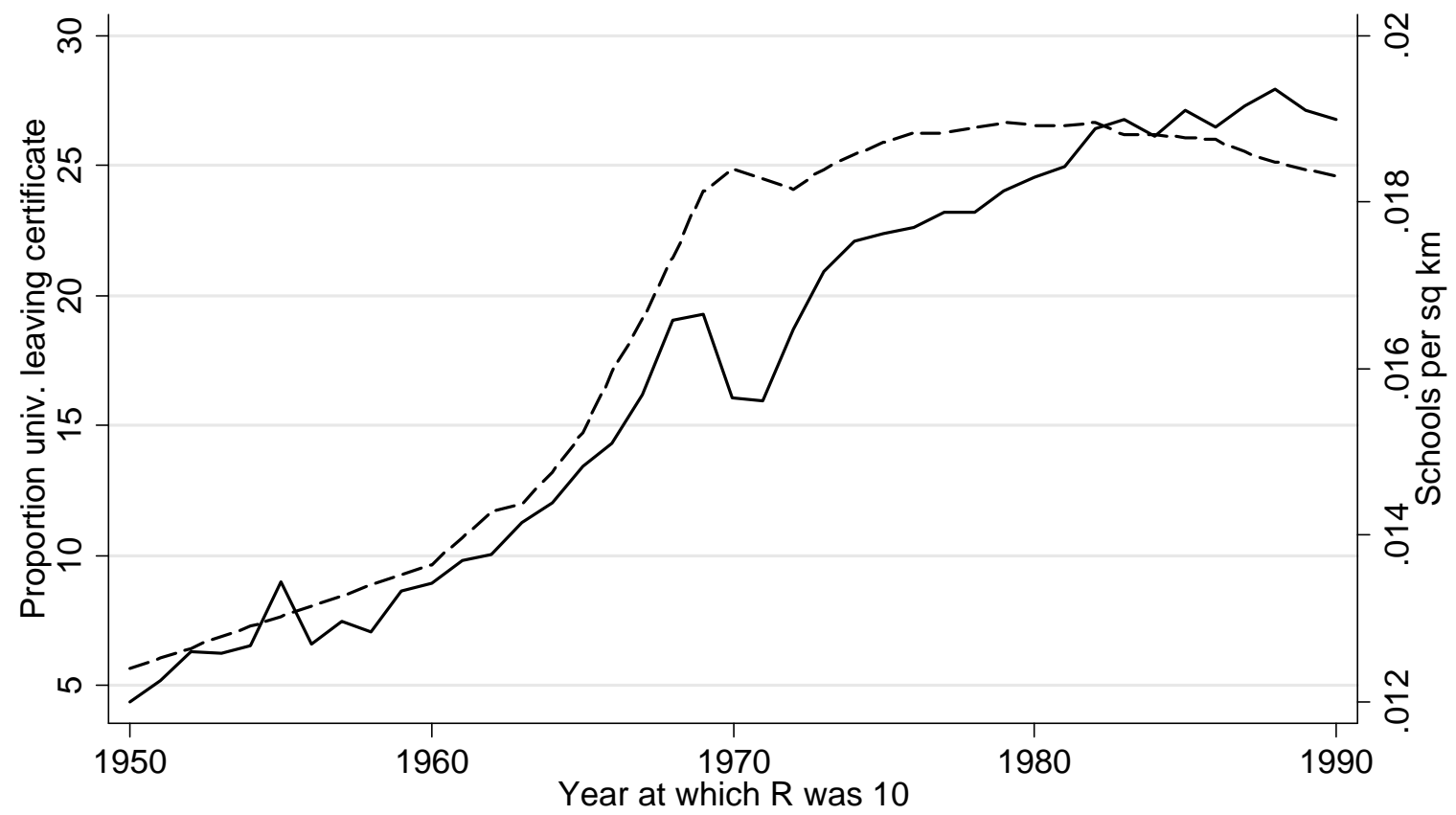

Proportion univ. leaving certificate ----- Schools per sq km 
Figure 4: Age/Cohort Trends in Smoking Rates

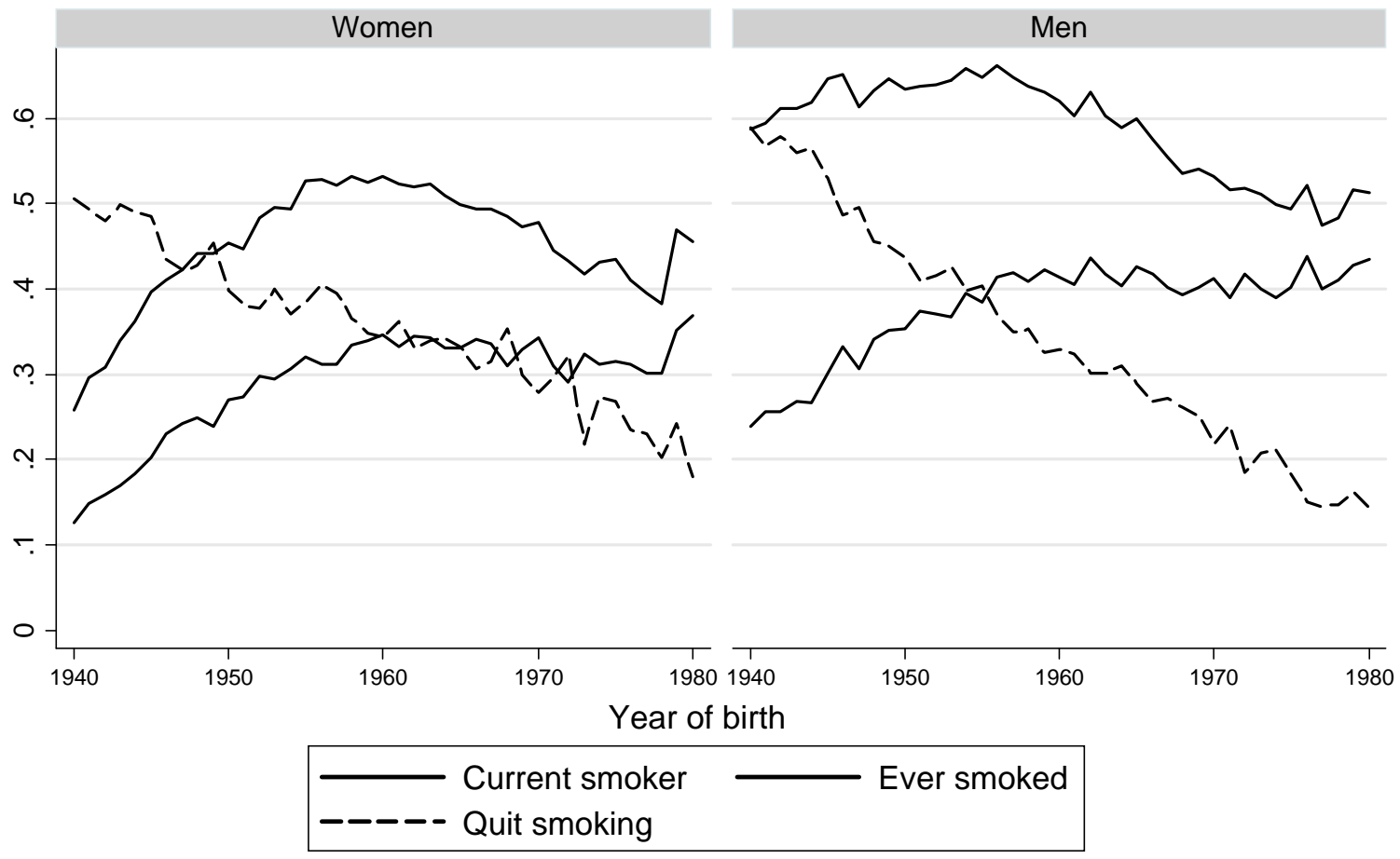


Figure 5: Age/Cohort Trends in Overweight and Obesity

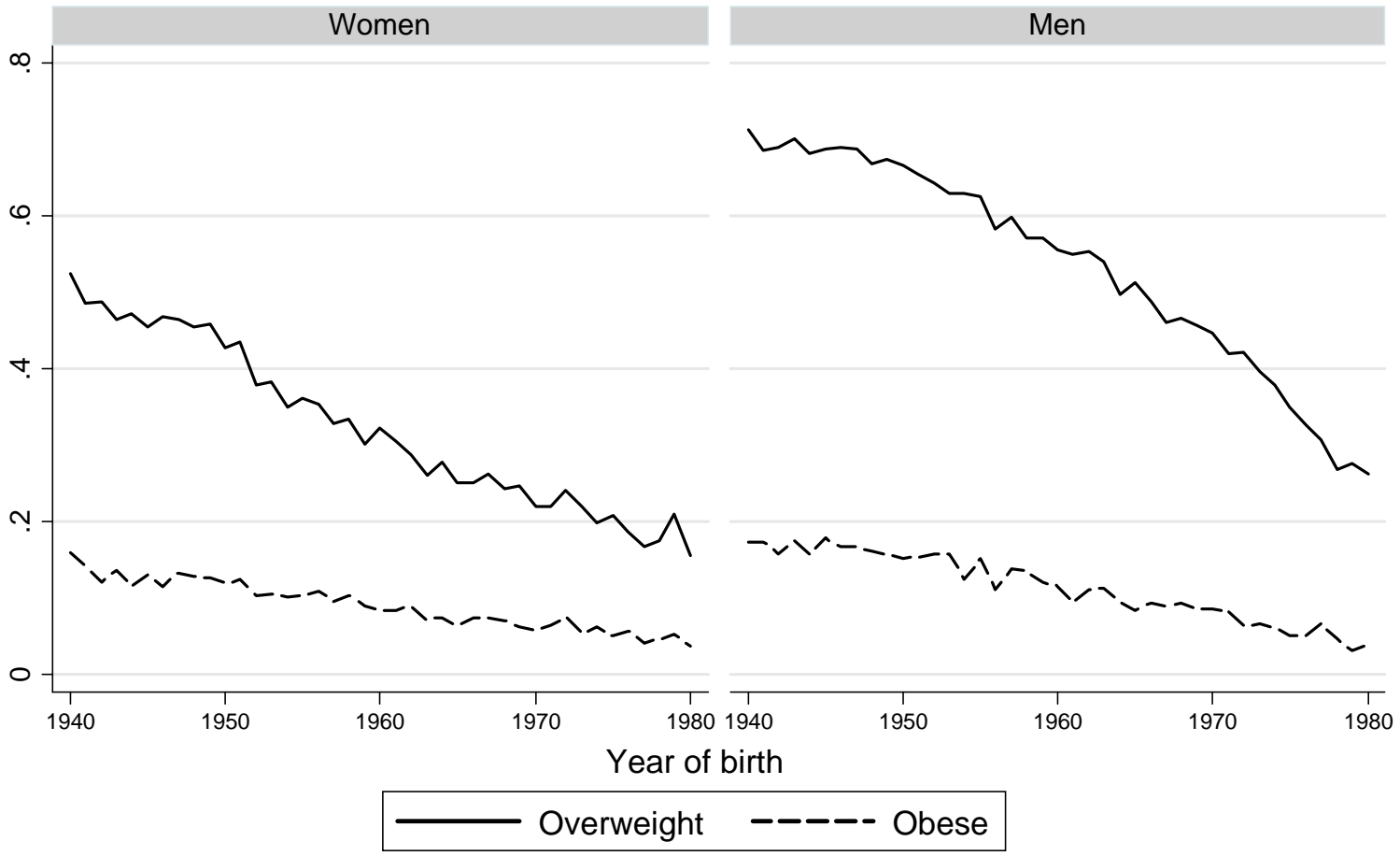




\section{Discussion Paper Series}

Mannheim Research Institute for the Economics of Aging, Universität Mannheim

To order copies, please direct your request to the author of the title in question.

\begin{tabular}{|c|c|c|c|}
\hline Nr. & Autoren & Titel & Jahr \\
\hline $174-09$ & $\begin{array}{l}\text { Axel Börsch-Supan, } \\
\text { Tabea Bucher-Koenen, } \\
\text { Martin Gasche und } \\
\text { Christina Benita Wilke }\end{array}$ & $\begin{array}{l}\text { Ein einheitliches Rentensystem für } \\
\text { Ost- und Westdeutschland - } \\
\text { Simulationsrechnungen zum Reformvorschlag } \\
\text { des Sachverständigenrates }\end{array}$ & 09 \\
\hline $175-09$ & $\begin{array}{l}\text { Steffen Reinhold, } \\
\text { Hendrik Jürges }\end{array}$ & Parental Income and Child Health in Germany & 09 \\
\hline $176-09$ & $\begin{array}{l}\text { Karsten Hank, Marcel } \\
\text { Erlinghagen }\end{array}$ & $\begin{array}{l}\text { Perceptions of Job Security in Europe's Ageing } \\
\text { Workforce }\end{array}$ & 09 \\
\hline $177-09$ & $\begin{array}{l}\text { Hendrik Jürges, } \\
\text { Karsten Hank, }\end{array}$ & $\begin{array}{l}\text { The Last Year of Life in Europe: Initial findings } \\
\text { from the SHARE study }\end{array}$ & 09 \\
\hline $178-09$ & Steffen Reinhold & $\begin{array}{l}\text { Reassessing the Link between Premarital } \\
\text { Cohabitation and Marital Instability }\end{array}$ & 09 \\
\hline $179-09$ & $\begin{array}{l}\text { Alexander Ludwig, } \\
\text { Edgar Vogel }\end{array}$ & $\begin{array}{l}\text { Mortality, Fertility, Education and Capital } \\
\text { Accumulation in a simple OLG Economy }\end{array}$ & 09 \\
\hline $180-09$ & Edgar Vogel & $\begin{array}{l}\text { From Malthus to Modern Growth: Child Labor, } \\
\text { Schooling and Human Capital }\end{array}$ & 09 \\
\hline 181-09 & $\begin{array}{l}\text { Steffen Reinhold, } \\
\text { Hendrik Jürges }\end{array}$ & $\begin{array}{l}\text { Secondary School Fees and the Causal Effect } \\
\text { of Schooling on Health Behaviour }\end{array}$ & 09 \\
\hline $182-09$ & $\begin{array}{l}\text { Steffen Reinhold, } \\
\text { Kevin Thom }\end{array}$ & $\begin{array}{l}\text { Temporary Migration and Skill Upgrading: } \\
\text { Evidence from Mexican Migrants }\end{array}$ & 09 \\
\hline $183-09$ & $\begin{array}{l}\text { Hendrik Jürges, } \\
\text { Eberhard Kruk, Steffen } \\
\text { Reinhold }\end{array}$ & $\begin{array}{l}\text { The effect of compulsory schooling on health - } \\
\text { evidence from biomarkers }\end{array}$ & 09 \\
\hline $184-09$ & $\begin{array}{l}\text { Nicola Fuchs- } \\
\text { Schündeln, Dirk } \\
\text { Krüger, Mathias } \\
\text { Sommer } \\
\end{array}$ & $\begin{array}{l}\text { Inequality Trends for Germany in the Last Two } \\
\text { Decades: A Tale of Two Countries }\end{array}$ & 09 \\
\hline $185-09$ & $\begin{array}{l}\text { Francesco Cinnirella, } \\
\text { Joachim Winter }\end{array}$ & $\begin{array}{l}\text { Size Matters! Body Height and Labor Market } \\
\text { Discrimination: A Cross-European Analysis }\end{array}$ & 09 \\
\hline $186-09$ & $\begin{array}{l}\text { Hendrik Jürges, } \\
\text { Steffen Reinhold, } \\
\text { Martin Salm }\end{array}$ & $\begin{array}{l}\text { Does Schooling Affect Health Behavior? } \\
\text { Evidence from Educational Expansion in } \\
\text { Western Germany }\end{array}$ & 09 \\
\hline
\end{tabular}

